\title{
A study on natural and manmade global interannual fluctuations of cirrus cloud cover for the period 1984-2004
}

\author{
K. Eleftheratos ${ }^{1,2}$, C. S. Zerefos ${ }^{1,2,3}$, P. Zanis ${ }^{4}$, D. S. Balis ${ }^{5}$, G. Tselioudis ${ }^{6}$, K. Gierens ${ }^{7}$, and R. Sausen ${ }^{7}$ \\ ${ }^{1}$ Laboratory of Climatology \& Atmospheric Environment, University of Athens, Greece \\ ${ }^{2}$ Foundation for Biomedical Research, Academy of Athens, Greece \\ ${ }^{3}$ National Observatory of Athens, Greece \\ ${ }^{4}$ Department of Meteorology and Climatology, Aristotle University of Thessaloniki, Greece \\ ${ }^{5}$ Laboratory of Atmospheric Physics, Aristotle University of Thessaloniki, Greece \\ ${ }^{6}$ Goddard Institute for Space Studies, National Aeronautics and Space Administration, USA \\ ${ }^{7}$ Institute of Atmospheric Physics, DLR, Germany
}

Received: 17 November 2006 - Published in Atmos. Chem. Phys. Discuss.: 5 January 2007

Revised: 5 April 2007 - Accepted: 4 May 2007 - Published: 21 May 2007

\begin{abstract}
The seasonal variability and the interannual variance explained by ENSO and NAO to cirrus cloud cover (CCC) are examined during the twenty-year period 19842004. CCC was found to be significantly correlated with vertical velocities and relative humidity from ECMWF/ERA40 in the tropics (correlations up to -0.7 and +0.7 at some locations, respectively) suggesting that variations in large-scale vertical winds and relative humidity fields can be the origin of up to half of the local variability in CCC over these regions. These correlations reflect mostly the seasonal cycle. Although the annual cycle is dominant in all latitudes and longitudes, peaking over the tropics and subtropics, its amplitude can be exceeded during strong El Nino/La Nina events. Over the eastern tropical Pacific Ocean the interannual variance of CCC which can be explained by ENSO is about $6.8 \%$ and it is $\sim 2.3$ times larger than the amplitude of the annual cycle. Natural long-term trends in the tropics are generally small (about $-0.3 \%$ cloud cover per decade) and possible manmade trends in those regions are also small. The contributions of NAO and QBO to the variance of CCC in the tropics are also small. In the northern mid-latitudes, on the other hand, the effect of NAO is more significant and can be very important regionally. Over northern Europe and the eastern part of the North Atlantic Flight Corridor (NAFC) there is a small positive correlation between $\mathrm{CCC}$ and NAO index during the wintertime of about 0.3 . In this region, the interannual variance of CCC explained by NAO is $2.6 \%$ and the amplitude of the annual cycle is $3.1 \%$. Long-term trends
\end{abstract}

Correspondence to: K. Eleftheratos

(kelef@geol.uoa.gr) over this region are about $+1.6 \%$ cloud cover per decade and compare well with the observed manmade trends over congested air traffic regions in Europe and the North Atlantic as have been evidenced from earlier findings.

\section{Introduction}

Large-scale natural fluctuations such as the El Nino/Southern Oscillation (ENSO) and North Atlantic Oscillation (NAO) are known to alter the distribution and natural variability of various atmospheric parameters (i.e. temperature, precipitation) including cloudiness. Their impact, however, on the natural variability of cirrus clouds is less well quantified and much less it is known about the relative roles of long-term manmade (aviation) trends and natural variability.

Cirrus clouds are optically thin and non-black high, cold clouds composed of ice crystals. Along with low marine stratus clouds, they are the principal cloud type controlling the Earth's radiation budget (Lynch, 1996). Thin cirrus clouds are of significant climatological importance because they produce net heating of the planet. The relatively large particles efficiently scatter sunlight into the forward (downward) direction and thus do not prevent sunlight from reaching the Earth. In the thermal infrared, ice is highly absorptive (and thus highly emissive) and it reradiates part of the energy it receives from the Earth back to the planet (Lynch, 1996).

The distribution of cirrus clouds in the upper troposphere has been examined mainly by satellite observations, which provide global coverage (Liou, 1986; Woodbury and McCormick, 1986; Wang et al., 1996; Wylie and Menzel, 1999;

Published by Copernicus GmbH on behalf of the European Geosciences Union. 
Sandor et al., 2000; Sassen and Campbell, 2001; Dessler and Yang, 2003; Bourassa et al., 2005; Chen and Liu, 2005). In the tropics, active tropical cumulonimbus clouds transport large amounts of ice water to the upper troposphere and generate extensive cirrus outflow anvils. Ice crystals can also be generated in situ by slow, synoptic scale uplift of a humid layer (Jensen et al., 1996). At mid-latitudes their formation is linked to synoptic and frontal weather systems (Sassen and Campbell, 2001). Mid-latitude cirrus clouds form in ice-supersaturated regions (ISSRs, Gierens et al., 1999, 2000) the global distribution of which has been described by Spichtinger et al. (2003).

Previous studies examining the effects of El Nino on upper tropospheric cirrus have based their results on observations by satellites from space (Wang et al., 1996; Mergenthaler et al., 1999; Sandor et al., 2000; Massie et al., 2000; Cess et al. 2001). Massie et al. (2000) analysed geographical distributions of aerosol extinction data in the troposphere and stratosphere for 1993-1998 from the Halogen Occultation Experiment (HALOE) and showed that during El Nino conditions of 1997 upper tropospheric cirrus increased over the mid-Pacific and decreased over Indonesia. Longitudinal centroids of cirrus in the Pacific and over Indonesia shifted eastward by $25^{\circ}$ in the troposphere in 1997 whereas longitudinal centroids of aerosol in the lower stratosphere did not exhibit longitudinal shifts in 1997, indicating that the effects of El Nino upon equatorial particle distributions are confined to the troposphere. More recently, Wang et al. (2003) examined the characteristics of cloud distributions with emphasis on cloud longwave radiative forcing during the peak of the 1997/1998 El Nino in relation to climatological conditions, based on SAGE II measurements. Their results indicated above-normal high-altitude opaque cloud occurrence over the eastern tropical Pacific and an opposite situation over the Pacific warm pool, generally consistent with the pattern of the tropical sea surface temperature and precipitation anomalies. A similar behavior was also noticed in the distribution of subvisual clouds near the tropical tropopause.

In the present study we calculate the percent of the interannual variance of CCC, caused by ENSO, NAO and longterm trends. The results are also compared with observed long-term trends in CCC over congested air traffic regions in Europe and the North Atlantic (Zerefos et al., 2003; Stordal et al., 2005; Stubenrauch and Schumann, 2005) to evaluate the significance of the anthropogenic (aviation) effect with respect to the natural variability. To account for dynamical and thermo-dynamical influences on CCC variability, cirrus cloud averages have been studied in relation to large-scale meteorological parameters such as vertical velocities and relative humidity.

It is important to note the objective of this analysis and how it is different from previous such works. Why is it important to know the scales of variability of cirrus clouds? It should be also pointed out that now we have available more than two decades of cloud cover from ISCCP that include several ENSO and NAO cycles. This along with the availability of detailed atmospheric conditions data from the reanalyses products allows us for the first time to conduct a complete study of the time and space scales of variability of cirrus cloud cover along with an analysis of the dynamic and thermodynamic influences on the cirrus cloud cover. The availability of this long dataset and the completeness of the analysed time and space scales and dependencies distinguish this work from previous ones.

\section{Data sources and methodology}

The cloud data set analysed in this study was produced by the International Satellite Cloud Climatology Project (ISCCP) (Rossow and Schiffer, 1991; Rossow et al., 1996). The latest available (D2) version of the data set used in this study has a spatial resolution of $280 \mathrm{~km}\left(2.5^{\circ}\right.$ at the equator) and covers the period 1984-2004. The data set provides monthly averages of cloud properties of fifteen different cloud types based on radiometric definitions that rely on cloud optical thickness and cloud top pressure. Use was made of the equal-angle map grid of D2 version which has equal $2.5^{\circ}$ increments in latitude and longitude providing data at latitudes from $-90^{\circ}$ to $90^{\circ}$ and longitudes from $0^{\circ}$ to $360^{\circ}$ (positive eastward). In the ISCCP D2 satellite cloud dataset, cirrus clouds are defined as those with optical thickness less than 3.6 and cloud top pressure less than $440 \mathrm{mb}$. High cloud amounts from this data set have been compared with those from SAGE II (Liao et al., 1995) and have been recently used in several contrailcirrus-climate studies (Zerefos et al., 2003; Minnis et al., 2004; Stordal et al., 2005). In order to avoid artificial satellite cloud retrievals after the Mt. Pinatubo eruption in 1991 (Rossow and Schiffer, 1999; Luo et al., 2002) cirrus cloud data taken in 1991 and 1992 were not used in our analysis.

To examine the consistency of the ISCCP data we also analysed vertical velocities and relative humidity at $300 \mathrm{hPa}$ from the ECMWF/ERA40 Reanalysis datasets (http://data. ecmwf.int/data/d/era40_moda/). The level of $300 \mathrm{hPa}$ was selected in this study as a compromise for an upper tropospheric level for both the tropics and the middle and the high latitudes. However, we have looked also at $200 \mathrm{hPa}$ for the tropics. ERA40 data contain daily and monthly averages of various natural parameters at the surface and at various pressure levels from September 1957 to August 2002. Data are provided on $2.5^{\circ} \times 2.5^{\circ}$ grid boxes at latitudes from $90^{\circ}$ to $-90^{\circ}$ and longitudes from $0^{\circ}$ to $360^{\circ}$ (positive eastward). In order to be as close as possible to the ISCCP data we made use of ERA40 data for the period 1984-2001. For brevity, the terms VV300 and RH300 were used to indicate the vertical velocities and relative humidity at $300 \mathrm{hPa}$.

Cirrus cloud amounts from ISCCP were correlated with vertical velocities from ERA40 based on a simple regression statistical model:

$\operatorname{CCC}(i, j)=a \times \operatorname{VV} 300(i, j)+b$ 
Where $i$ denotes the month and $j$ is the year of the examined variables, $a$ is the slope and $b$ is the intercept of the regression model. Equation (1) was also used for the calculation of correlation coefficients between CCC and RH300. The correlation analysis between the examined parameters was performed at each individual grid box $2.5^{\circ} \times 2.5^{\circ}$ from January 1984 to December 2001 (data points, $N=216$ ). The effect of ENSO on cirrus clouds has been examined by linear regression analysis between monthly mean CCC and Southern Oscillation Index (SOI) in the examined 21-years period, using the model described in Eq. (1). The occurrence of decadalscale changes in cloud frequency in the tropics (Wang et al., 2002) could affect our correlation analysis if they were not taken into account. In order to avoid possible effects from decadal changes in cloud occurrence in the tropics, we first removed from cirrus coverage variability related to the seasonal cycle and long-term trends for the period 1984-2004 based on the following regression model:

$\mathrm{CCC}(i, j)=S(i, j)+T(i, j)+$ residuals

Where $i$ denotes the month and $j$ is the year of CCC and its components, i.e. the seasonal (S) and the long-term trend (T) as described by Zerefos et al. (1994). The deseasonalized time series of CCC at each grid box was calculated by subtracting from each individual monthly value the overall mean monthly value for the whole period 1984-2004. The trend component was removed with linear regression analysis which was applied at each grid box between the deseasonalized time series of CCC and the time. The residuals from Eq. (2) were used as input for the correlation analysis between the anomalies of CCC and SOI. SOI was provided by the Bureau of Meteorology of the Australian Government at http://www.bom.gov.au/climate/current/soi2.shtml. The correlation between CCC and NAO index has been computed for the winter months (December, January and February) over Europe and the North Atlantic. The NAO index was provided by the Climate Analysis Section at http://www.cgd.ucar.edu/ cas/jhurrell/indices.html. The results from the correlation analyses are described in Sects. 3.2 and 3.3. In Sect. 3.1 we provide a short overview of the basic climatological characteristics of cirrus clouds from the ISCCP dataset on which we base all the analysis.

\section{Results and discussion}

\subsection{Climatological characteristics of cirrus clouds}

Figure 1 shows the global distribution of annual mean CCC from ISCCP for the period 1984-2004. In general, the geographical features of CCC from ISCCP are consistent with those published in earlier studies (Woodbury and McCormick, 1986; Wang et al., 1996; Wylie and Menzel, 1999; Bourassa et al., 2005). More analytically, the region bounded by latitudes $20^{\circ} \mathrm{N}-20^{\circ} \mathrm{S}$ and by longitudes $60^{\circ} \mathrm{E}-170^{\circ} \mathrm{W}$ is

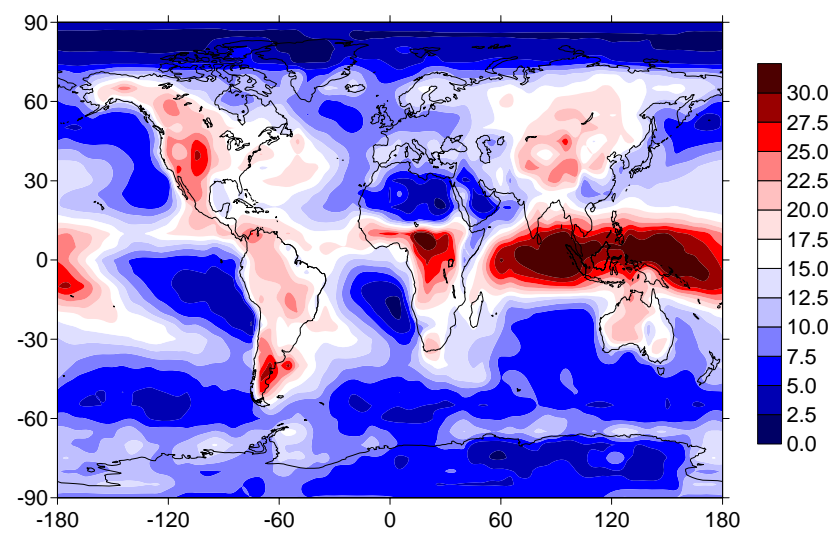

Fig. 1. Global map of annual mean CCC from 1984 to 2004 by ISCCP (in \% cloud cover).

the area of the Earth covered by the largest amounts of cirrus clouds. Their generation over this region is associated with two important features of the general circulation, the Walker circulation along the equator and the Monsoon wind system in Southeast Asia. High cirrus amounts are also observed over the South Pacific Convergence Zone, the Amazon area and central Africa as a result of strong upward air motions and high amounts of upper tropospheric humidity. At latitudes near $30^{\circ}$, the existence of subtropical high pressure belts limits the formation of cirrus clouds and therefore CCC over the subtropical zones is significantly lower than over the tropics. More specifically, low amounts of cirrus are found over extensive ocean regions, i.e. off the western coasts of South America and South Africa while in the northern subtropics low CCC is found over the Pacific Ocean off the western coasts of North America, the Saharan desert and the Arabian Peninsula.

As we move to higher latitudes, cirrus clouds concentrate over regions with highland climate (group H in Köppen's climatic classification system), i.e. the high mountain chains of the Rocky and Appalachian Mountains in North America, the southern part of the Andes in South America, the Himalayas and the Tibetan Plateau in Asia. Although not apparent from Fig. 1, these are mainly orographically induced cirrus clouds (the spatial scales of the vertical air motions are not resolved in the ERA40 data). The large amounts of cirrus clouds over the Tibetan Plateau, which occurs from March to April, is believed to be generated by relatively warm and moist air being slowly lifted over a large area by an approaching cold front and topographic lifting (Chen and Liu, 2005). In addition, the high amounts of cirrus over the greater area of Asia could be related to the formation of the Tibetan low pressure cell during the summer. Apart from orographic generation of cirrus wave clouds because of the mountainous terrains, natural cirrus cloud formation over the northern mid-latitudes is also related to synoptic and meso-scale weather patterns such as movements of jet streams and frontal systems (Sassen and 

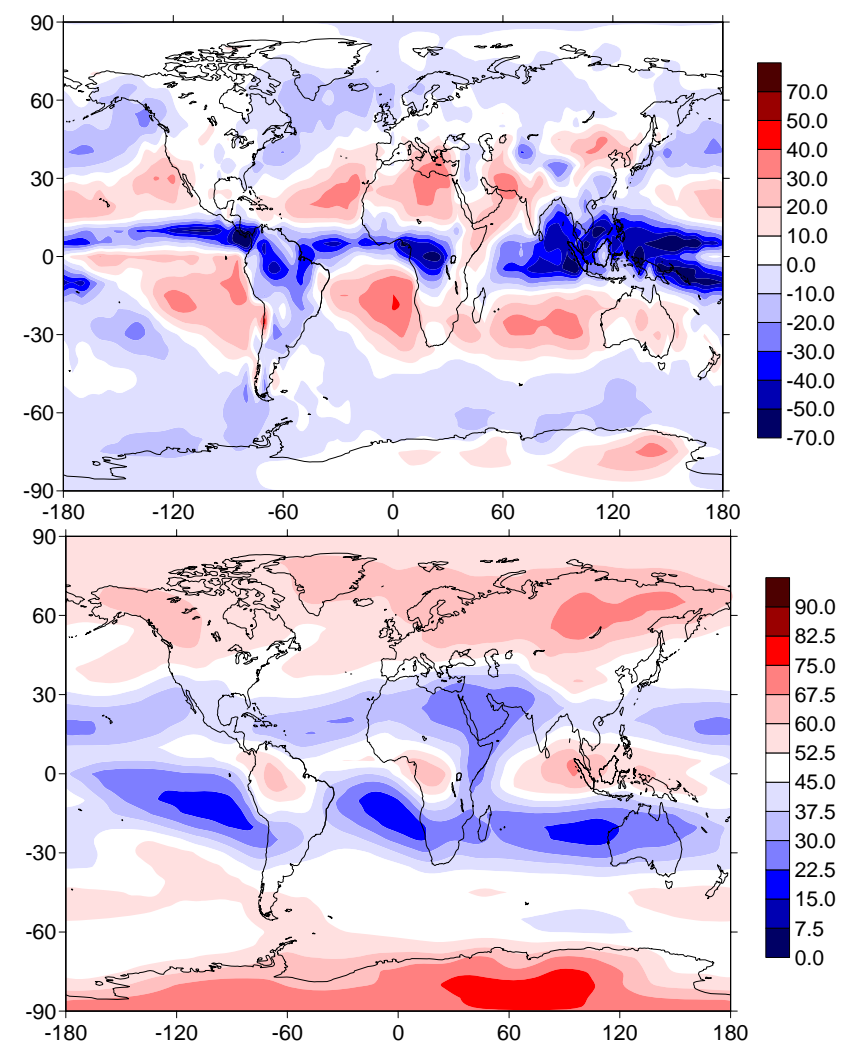

Fig. 2. (a) Global map of annual mean VV300 from 1984 to 2001 by ECMWF/ERA40 (in $\mathrm{mPa} / \mathrm{s}$ ). The negative and the positive values indicate the upward and the downward air motions respectively. The more negative (positive) the value is, the more upward (downward) the air motion. (b) Same as (a) but for the annual mean RH300 (in \%).

Cambell, 2001). Meso-scale gravity waves may also generate ice-supersaturated regions due to lifting of air masses and trigger the formation of optically thick natural cirrus clouds (Spichtinger et al., 2005). In the middle and high latitudes of the Southern Hemisphere where most of the surface is covered by water, there are low amounts of cirrus over the entire zones.

Apart from their natural formation, cirrus cloud formation over the high air traffic northern mid-latitudes is also related to anthropogenic sources such as aviation activities (Zerefos et al., 2003; Minnis et al., 2004; Stordal et al., 2005; Stubenrauch and Schumann, 2005). Air traffic may contribute to high-level cloudiness by producing contrails (direct effect), which can then be transformed into contrail-cirrus clouds, or indirectly, by emitting soot and other particles which can stay in the atmosphere and get involved in cloud formation processes (Lohmann and Feichter, 2005; Sausen et al., 2005; Schumann, 2005). However, in the tropics it is difficult to detect possible effects of regional persistent contrails on cirrus cloud trends. This is because trends in dynamics and thermo- dynamics mask possible man-made trends in cirrus clouds in those regions. Taking also into account that flight frequencies and fuel consumption are moderate over the tropical air traffic corridors, it makes it even more difficult to detect and quantify any possible anthropogenic effects (Zerefos et al., 2007).

3.2 Comparison with large-scale meteorological parameters

The corresponding distributions of annual mean VV300 and annual mean RH300 from ECMWF/ERA40 are shown in Figs. 2a and b. In the vertical velocities map (Fig. 2a), the negative values indicate the upward air motions and the positive values indicate downward air motions. Regions shown by blue and dark blue colors are regions where we usually find strong upward air motions, while regions shown by red and dark red colors are regions where we usually find strong downward air motions. As can be seen from Figs. 1 and 2 , there are consistent similarities between the geographical distributions of CCC, VV300 and RH300, indicating the existence of strong links of cirrus clouds with dynamical parameters. It also appears that natural cirrus clouds are preferably formed along major atmospheric circulation cells.

In regions with downward air motions and low relative humidity CCC is lower while over regions with upward air motions and high relative humidity CCC is higher. This suggests that over these regions the formation of cirrus clouds is related to the formation of deep convective cloud systems and therefore to convective activity. In order to better understand the relations between CCC, VV300 and RH300, Fig. 3a shows the correlation coefficients, $R$, between monthly mean CCC and monthly mean VV300 from January 1984 to December 2001 in each map grid box and Fig. 3b shows the respective R between CCC and RH300. From Fig. 3a it appears that the highest correlations between CCC and VV300 are found in the tropics and subtropics $\left(30^{\circ} \mathrm{N}-30^{\circ} \mathrm{S}\right)$. At some locations there is a $R^{2}=0.5$ coefficient of determination between the large-scale vertical velocity field and CCC which means that variations in the large-scale vertical velocity field are the origin of up to half of the local variability in CCC. The remaining variability can probably be explained by unresolved dynamics (meso-scale and micro-scale), and unresolved variations in the humidity, temperature, and aerosol fields. Also, cirrus clouds detached from the convective activity contribute to the remaining variability. At the level of $200 \mathrm{hPa}$ in the tropics and subtropics the respective correlation coefficients between cirrus clouds and vertical velocities are similar to those observed in Fig. 3a. In the mid-latitudes on the other hand, where the correlation coefficients are lower, the formation of cirrus clouds is less related to largescale convection and more affected by synoptic and mesoscale systems. In such systems, cirrus clouds are formed in pre-frontal regimes with weak dynamic forcings and are not well correlated with the large scale baroclinic updrafts. 
In addition, they often occur in combination with low level clouds and, due to the resulting mid-tropospheric thermal emission level, are classified as middle level clouds by ISCCP (Tselioudis and Jakob, 2002). The lower correlation in the mid-latitudes is probably also due to higher influence of unresolved dynamics (i.e. gravity waves, meso-scale influence), and potentially also due to a larger importance of heterogeneous nucleation processes in the polluted air masses of the northern mid-latitudes (Gierens et al., 2000).

A significant part of the correlations in Fig. 3 could be attributed to the seasonal cycle of the examined parameters which is quite distinct. Figure 4 shows the seasonal variations of zonal mean CCC averaged for the period 1984-2004 as well as of VV300 and RH300 averaged for the period 1984-2001. From Fig. 4 it appears that there is high correlation between the seasonal cycles of the examined parameters, indicated by their close seasonal match. As it was previously discussed, the higher correlations are found in the tropics $\left(30^{\circ} \mathrm{N}-30^{\circ} \mathrm{S}\right)$ comprising about $50 \%$ of the Earth's surface. Most obvious is the northward movement of the Hadley circulation cell during June, July and August. In boreal spring and summer there are higher amounts of CCC in the tropics as compared to the winter due to stronger upward air motions and higher relative humidity resulting from the Asian Monsoon. Over the subtropics, there are lower amounts of CCC due to dominating downward motions of air masses. Over middle and high latitudes where CCC is less correlated to large-scale vertical velocities the seasonal variations do not exhibit consistent patterns except for a Northern Hemisphere winter maximum.

Table 1 summarizes the seasonal and annual average amounts of CCC for the period 1984-2004 over six latitudinal belts: the northern mid-latitudes $\left(30^{\circ} \mathrm{N}-60^{\circ} \mathrm{N}\right)$, the northern subtropics $\left(15^{\circ} \mathrm{N}-30^{\circ} \mathrm{N}\right)$, the tropics $\left(15^{\circ} \mathrm{N}-\right.$ $\left.15^{\circ} \mathrm{S}\right)$, the southern subtropics $\left(15^{\circ} \mathrm{S}-30^{\circ} \mathrm{S}\right)$, the southern mid-latitudes $\left(30^{\circ} \mathrm{S}-60^{\circ} \mathrm{S}\right)$ and the global region $\left(60^{\circ} \mathrm{N}-\right.$ $60^{\circ} \mathrm{S}$ ). As can be seen from Table 1, the highest amounts of cirrus clouds are found over the tropical deep convective areas in all seasons. In the tropics, the annual mean cirrus coverage (according to ISCCP) is about $20 \%$ and the amplitude of the annual cycle is $\sim 2.7 \%$. The lowest and highest coverage in the tropics is about $18 \%$ and $22 \%$, corresponding to the summertime and springtime averages, respectively. Over the northern and the southern subtropics CCC averages to about $12 \%$ annually and the amplitudes of the annual cycle are about $3.5 \%$ and $4.7 \%$ respectively. Over the northern mid-latitudes CCC can range from about $12 \%$ in winter to about $14 \%$ in spring. The lowest amounts of CCC in all seasons are found over the oceans of the southern mid-latitudes. Globally $\left(60^{\circ} \mathrm{N}-60^{\circ} \mathrm{S}\right)$, cirrus clouds cover about $14 \%$ of the Earth's upper troposphere (ISCCP 1984-2004 annual average) and the amplitude of the annual cycle is about $1.2 \%$. Table 1 also shows the long-term changes in CCC from January 1984 to December 2004 over the examined regions after removing the annual cycle. According to ISCCP, cirrus
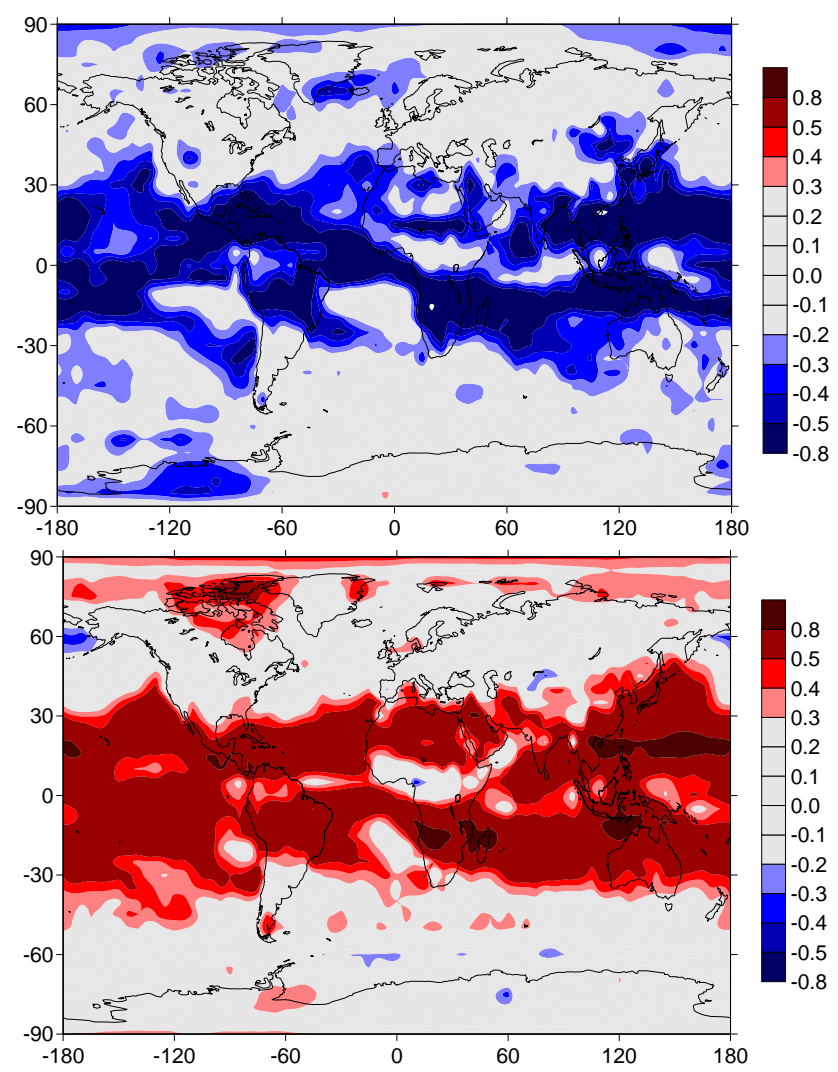

Fig. 3. (a) Global map of correlation coefficients between monthly mean CCC and monthly mean VV300 from January 1984 to December 2001. Only correlation coefficients above/below \pm 0.3 are shown. The highest correlations between cirrus clouds and largescale vertical velocities (up to -0.7 at some locations) are found in the tropics. (b) Same as (a) but between CCC and RH300.

clouds tend to decrease everywhere in the globe except over the southern mid-latitudes where no trends are observed.

It should be noted that the average cirrus amounts, which are shown in Table 1, depend on the satellite instrument used to obtain the cirrus data and the thresholds that are used to define cirrus clouds. Therefore different satellite climatologies can provide different cirrus cloud amounts. The frequency of all high-level clouds from SAGE II, for example, is about 3 times higher than the cloud amount from ISCCP with little seasonal variation (Liao et al., 1995). However, despite this large systematic difference, both datasets showed similar large-scale relative variations with latitude, which strengthens our findings (correlation between the zonal mean curves was high, 0.88 (99.99\% confidence level) for July and 0.82 ( $99.99 \%$ confidence level) for January).

\subsection{Natural fluctuations of cirrus clouds}

Although the annual cycle is dominant in all latitudes and longitudes, peaking over the tropics and subtropics, its 

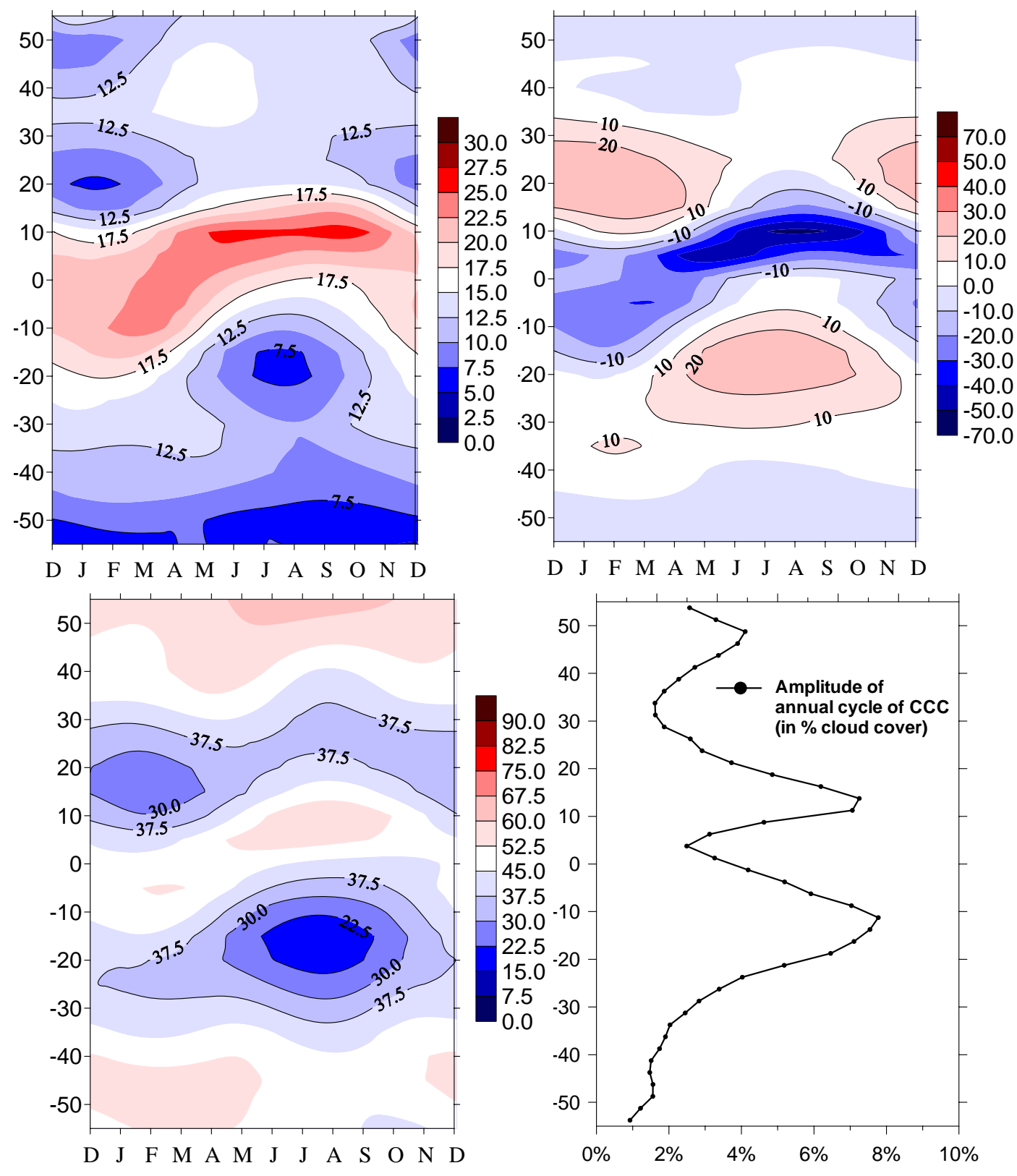

Fig. 4. (a) Seasonal variations of zonal mean CCC (in \% cloud cover) averaged for the period 1984-2004. (b) Same as (a) but for VV300 (in $\mathrm{mPa} / \mathrm{s}$ ) averaged for the period 1984-2001. (c) Same as (b) but for RH300 (in \%). (d) Amplitude of annual cycle of CCC (in \% cloud cover) at each latitudinal belt $\left(2.5^{\circ}\right)$.

amplitude can be exceeded under circumstances of strong El Nino/La Nina events. After removing from the time series of cirrus coverage the variability related to the seasonal cycle and long-term trends, ENSO signals become dominant over the eastern and western tropical Pacific Ocean, determining a significant part of the cirrus cloud interannual natural variability. Figure 5 shows the correlation coefficients between the deseasonalized and detrended time series of CCC and SOI from $60^{\circ} \mathrm{N}$ to $60^{\circ} \mathrm{S}$. As can be seen from
Fig. 5, the strongest correlations between the two variables are found in the tropical Pacific. Negative correlation suggests large amounts of thin cirrus clouds during warm (El Nino) episodes and positive correlation their absence. More analytically, Fig. 6 shows the deseasonalized and detrended time series of CCC from 1984 to 2004 versus SOI over (a) the eastern tropical Pacific region $\left(10^{\circ} \mathrm{S}-10^{\circ} \mathrm{N}, 80^{\circ} \mathrm{W}-180^{\circ} \mathrm{W}\right)$ and (b) the western tropical Pacific region $\left(10^{\circ} \mathrm{S}-10^{\circ} \mathrm{N}\right.$, $\left.80^{\circ} \mathrm{E}-150^{\circ} \mathrm{E}\right)$. From Fig. 6 it appears that CCC is strongly 
Table 1. Seasonal and annual mean CCC (in \% cloud cover) in ISCCP D2 data from January 1984 to December 2004 over the northern mid-latitudes $\left(30^{\circ} \mathrm{N}-60^{\circ} \mathrm{N}\right)$, the northern subtropics $\left(15^{\circ} \mathrm{N}-30^{\circ} \mathrm{N}\right)$, the tropics $\left(15^{\circ} \mathrm{N}-15^{\circ} \mathrm{S}\right)$, the southern subtropics $\left(15^{\circ} \mathrm{S}-30^{\circ} \mathrm{S}\right)$, the southern mid-latitudes $\left(30^{\circ} \mathrm{S}-60^{\circ} \mathrm{S}\right)$ and the global region $\left(60^{\circ} \mathrm{N}-60^{\circ} \mathrm{S}\right)$. The amplitude of the annual cycle of CCC is in $\%$ cloud cover. Long-term trends are in \% cloud cover per decade. Underlined long-term trends are statistically significant at the $95 \%$ confidence level.

\begin{tabular}{|c|c|c|c|c|c|c|c|}
\hline 1984-2004 & Winter (DJF) & Spring (MAM) & Summer (JJA) & Autumn (SON) & Annual mean & Amplitude of annual cycle & Trend per decade \\
\hline $\begin{array}{l}\text { Northern } \\
\text { mid-latitudes }\end{array}$ & $11.7 \%$ & $14.2 \%$ & $14.1 \%$ & $13.5 \%$ & $13.4 \%$ & $\pm 2.0 \%$ & $\underline{-0.4 \%}$ \\
\hline Northern subtropics & $8.7 \%$ & $11.9 \%$ & $14.6 \%$ & $13.2 \%$ & $12.1 \%$ & $\pm 3.5 \%$ & $-0.3 \%$ \\
\hline Southern subtropics & $16.5 \%$ & $13.9 \%$ & $8.3 \%$ & $11.6 \%$ & $12.6 \%$ & $\pm 4.7 \%$ & $-0.7 \%$ \\
\hline $\begin{array}{l}\text { Southern } \\
\text { mid-latitudes }\end{array}$ & $9.5 \%$ & $9.8 \%$ & $8.5 \%$ & $8.5 \%$ & $9.1 \%$ & $\pm 0.9 \%$ & $\overline{+0.1 \%}$ \\
\hline
\end{tabular}

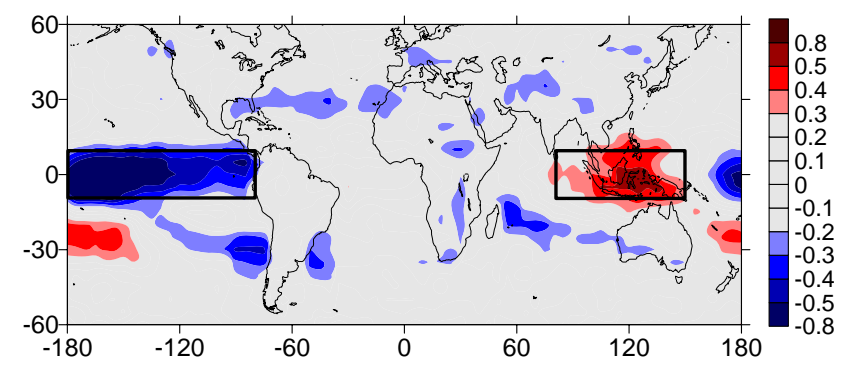

Fig. 5. Correlation coefficients between the deseasonalized and detrended time series of CCC and SOI from January 1984 to December 2004 in the region $\left(60^{\circ} \mathrm{N}-60^{\circ} \mathrm{S}\right)$. Only correlation coefficients above/below \pm 0.3 are shown. The highest correlations are found over the tropical Pacific Ocean. Rectangles show the regions in eastern and western Pacific in which cirrus cloud averages have been studied.

anti-correlated with SOI over eastern Pacific $(\mathrm{R}=-0.7)$ and positively correlated $(\mathrm{R}=+0.6)$ over its western part, which practically confirms the correlation map of Fig. 5. The two correlation coefficients are statistically significant at the $99 \%$ confidence level and suggest that southern oscillation and its associated events (warm and cold) play key roles in the distribution and appearance of thin cirrus clouds over these locations, explaining about one third to half of their large-scale natural variability.

The percent of the interannual variance of CCC explained by ENSO over the two locations was investigated by reconstructing the time series of CCC from SOI, based on the following linear regression model:

$a \times \operatorname{SOI}(i, j)+b=$ reconstructed $\mathrm{CCC}(i j)$

Where $a$ is the slope and $b$ is the intercept of the correlation analysis between the deseasonalized and detrended time series of $\mathrm{CCC}$ and SOI. The reconstructed time series of $\mathrm{CCC}$ at the two locations is shown in Fig. 6 by the lines with grey colour. The annual mean CCC, the amplitude of the annual cycle, the interannual variance explained by ENSO, and the

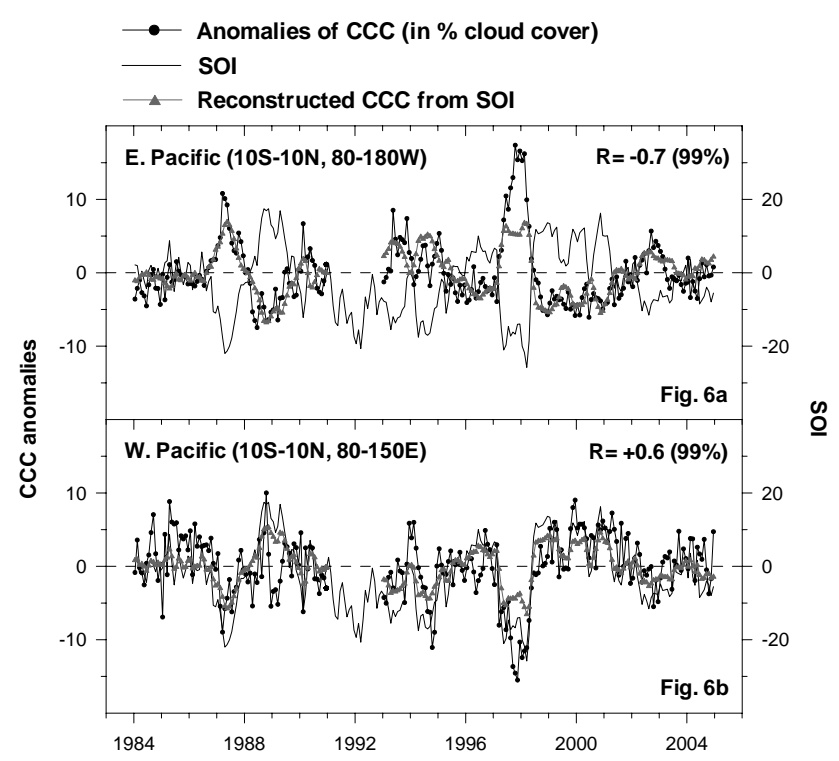

Fig. 6. (a) Time series of deseasonalized and detrended CCC from 1984 to 2004 and of SOI over the eastern tropical Pacific region $\left(10^{\circ} \mathrm{S}-10^{\circ} \mathrm{N}, 80^{\circ} \mathrm{W}-180^{\circ} \mathrm{W}\right)$. (b) Same as (a) but for the western tropical Pacific region $\left(10^{\circ} \mathrm{S}-10^{\circ} \mathrm{N}, 80^{\circ} \mathrm{E}-150^{\circ} \mathrm{E}\right) . R$ is the correlation coefficient between the two lines. Values in brackets refer to statistical significance of $R$. With grey colour is shown the reconstructed time series of CCC from SOI at the two locations, indicating the interannual variance of CCC explained by ENSO (in \% cloud cover).

long-term trends of CCC over the studied regions are summarised in Table 2a. As can be seen from Table 2a, over the eastern tropical Pacific Ocean the annual mean CCC is $12.5 \%$ and the amplitude of the annual cycle is $3 \%$. This means that CCC can range between $15.5 \%$ and $9.5 \%$. However, this amplitude can be exceeded during strong ENSO episodes. For example during El Nino 1986/87, La Nina 1988/89 and El Nino $1997 / 98$ (Fig. 6), the interannual variance of CCC explained by ENSO is $6.8 \%$ and it is about 2.3 times larger than the amplitude of the annual cycle. Accordingly, over 


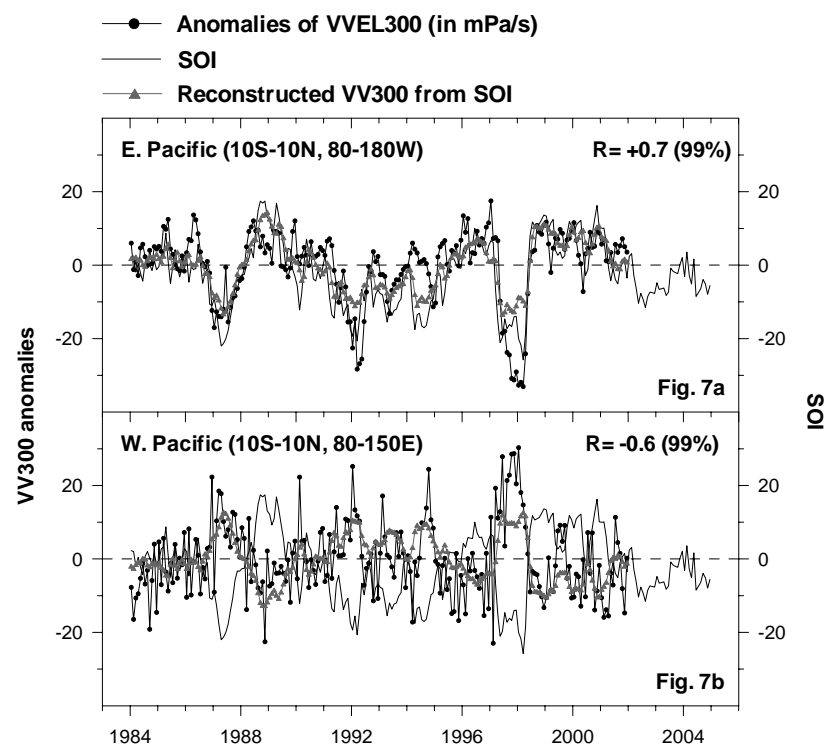

Fig. 7. (a) Time series of deseasonalized and detrended VV300 from 1984 to 2001 and of SOI over the eastern tropical Pacific region $\left(10^{\circ} \mathrm{S}-10^{\circ} \mathrm{N}, 80^{\circ} \mathrm{W}-180^{\circ} \mathrm{W}\right)$. (b) Same as (a) but for the western tropical Pacific region $\left(10^{\circ} \mathrm{S}-10^{\circ} \mathrm{N}, 80^{\circ} \mathrm{E}-150^{\circ} \mathrm{E}\right)$. $\mathrm{R}$ is the correlation coefficient between the two lines. Values in brackets refer to statistical significance of $R$. With grey colour is shown the reconstructed time series of VV300 from SOI at the two locations, indicating the interannual variance of VV300 explained by ENSO (in $\mathrm{mPa} / \mathrm{s}$ ).

the western part of the tropical Pacific the interannual variance of CCC explained by ENSO is 5.9\%, which is about 2.4 times larger than the amplitude of the annual cycle.

In order to further understand the altered equatorial CCC during Southern Oscillation episodes we also examined the correlations of the deseasonalized and detrended time series of VV300 with SOI (Fig. 7). As can be seen from Fig. 7, the correlation coefficients between the two variables over the examined locations are similar in magnitude with those observed in Fig. 6 but with opposite signs. The positive correlation in Fig. 7a suggests increased rising of warm moist air over the eastern tropical Pacific during El Nino and therefore enhanced convective activity in the area, whereas the negative correlation in Fig. $7 \mathrm{~b}$ indicates sinking air motion over its western part and therefore reduced convection during El Nino. This circulation was responsible for the observed variability of natural cirrus clouds in Fig. 6. For example, during El Nino 1997/98 CCC increased by more than 10\% over the eastern tropical Pacific due to enhanced convective activity, whereas reduced convective activity over its western part caused comparable decreases in agreement with the findings of earlier studies (Massie et al., 2000; Cess et al., 2001; Wang et al., 2003). The contribution of ENSO to the interannual variance of VV300 at the two regions is shown in Fig. 7 by the lines with grey colour. As a further illustration of the im-

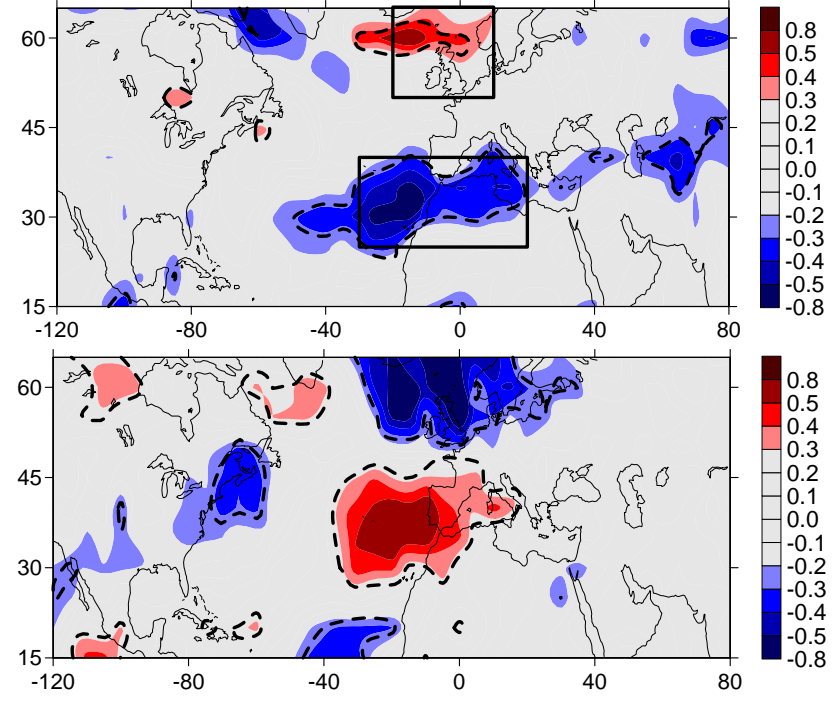

Fig. 8. (a) Correlation coefficients between the deseasonalized and detrended time series of CCC from 1984 to 2004 and NAO index during the wintertime (December, January and February) in the region $\left(15^{\circ} \mathrm{N}-65^{\circ} \mathrm{N}, 120^{\circ} \mathrm{W}-80^{\circ} \mathrm{E}\right)$. (b) Same as (a) but for VV300 from 1984 to 2001 . Only correlation coefficients above/below \pm 0.3 are shown. Dotted line bounds regions where correlation coefficients are statistically significant at the $95 \%$ confidence level (ttest). Rectangles show the regions in which cirrus cloud averages have been studied.

pact of the 1997/98 El Nino on the Earth-atmosphere system, Wang et al. (2003) estimated the changes in cloud longwave radiative forcing based on cloud observations from SAGE II. During the 1997/1998 El Nino, the magnitude of the cloud longwave radiative forcing was significantly reduced over the Pacific warm pool, Indonesia, northern South America and tropical Africa, implying increased outgoing longwave radiation. Concurrent with those changes was the greatly enhanced cloud longwave radiative forcing over the eastern $\mathrm{Pa}$ cific, corresponding to significantly reduced outgoing longwave radiation.

The other natural oscillation that has been examined as to its effect on CCC is the North Atlantic Oscillation (NAO). As it is known, NAO has two phases; a positive and a negative phase. The positive phase of NAO is characterized by an enhanced Icelandic low and an enhanced subtropical high pressure system resulting in a stronger pressure gradient with more and stronger winter storms crossing the Atlantic Ocean on a more northerly track, bringing moist air to northern Europe. Its negative phase is characterized by a weak Icelandic low and a weak subtropical high pressure system resulting in fewer and weaker winter storms crossing on a more west-east pathway, bringing moist air into the Mediterranean. Such mode of natural climate variability over North Atlantic and Europe could have an effect on cirrus clouds. To study 
Table 2. (a) Annual mean CCC (in \% cloud cover), amplitude of annual cycle of CCC (in \% cloud cover), interannual variance explained by ENSO (in \% cloud cover), and long-term trend (in \% cloud cover per decade) from January 1984 to December 2004 over the ENSO regions (Eastern Pacific; $10^{\circ} \mathrm{S}-10^{\circ} \mathrm{N}, 80^{\circ} \mathrm{W}-180^{\circ} \mathrm{W}$, Western Pacific; $10^{\circ} \mathrm{S}-10^{\circ} \mathrm{N}, 80^{\circ} \mathrm{E}-150^{\circ} \mathrm{E}$ ). (b) Same as (a) but for the NAO regions (Eastern part of the North Atlantic and the Mediterranean; $25^{\circ} \mathrm{N}-40^{\circ} \mathrm{N}, 30^{\circ} \mathrm{W}-20^{\circ} \mathrm{E}$, Northern Europe and the eastern part of NAFC; $\left.50^{\circ} \mathrm{N}-65^{\circ} \mathrm{N}, 20^{\circ} \mathrm{W}-10^{\circ} \mathrm{E}\right)$. Underlined long-term trends are statistically significant at the $95 \%$ confidence level.

\begin{tabular}{|c|c|c|c|c|}
\hline \multirow{2}{*}{$\begin{array}{l}\text { (a) } \\
1984-2004\end{array}$} & \multicolumn{4}{|c|}{ ENSO regions } \\
\hline & Annual mean & $\begin{array}{l}\text { Amplitude of annual cy- } \\
\text { cle }\end{array}$ & $\begin{array}{l}\text { Interannual variance explained } \\
\text { by ENSO }\end{array}$ & Trend per decade \\
\hline Western Pacific & $29.4 \%$ & $\pm 2.4 \%$ & $\pm 5.9 \%$ & $-2.3 \%$ \\
\hline (b) & \multicolumn{4}{|c|}{ NAO regions } \\
\hline $\begin{array}{l}\text { Eastern part of the North At- } \\
\text { lantic and the Mediterranean }\end{array}$ & $9 \%$ & $\pm 3.6 \%$ & $\pm 2.4 \%$ & $-0.5 \%$ \\
\hline $\begin{array}{l}\text { Northern Europe and the east- } \\
\text { ern part of NAFC }\end{array}$ & $8.5 \%$ & $\pm 3.1 \%$ & $\pm 2.6 \%$ & $+1.6 \%$ \\
\hline
\end{tabular}

this effect, Fig. 8 shows the correlation coefficients between the deseasonalized and detrended time series of CCC and NAO index during the wintertime (December, January and February) in the region bounded by latitudes $15^{\circ} \mathrm{N}-65^{\circ} \mathrm{N}$ and by longitudes $120^{\circ} \mathrm{W}-80^{\circ} \mathrm{E}$. For comparison purposes, the respective correlation coefficients between VV300 and NAO index are also presented. The positive correlations between CCC and NAO index are shown by red and dark red colours whereas the negative correlations by blue and dark blue colours. The dotted line in Fig. 8 bounds the regions where the correlation coefficients are statistically significant at the $95 \%$ confidence level (Student's t-test).

As can be seen from Fig. 8a, the correlation coefficients of $\mathrm{CCC}$ with NAO index during the wintertime show a dipole structure in the area, consisting of negative correlations over regions extending from the eastern part of the North Atlantic to the Mediterranean (up to -0.5 at some locations) and positive correlations over northern Europe and the eastern part of NAFC, explaining part of the cirrus cloud long-term natural variability. Over these regions, the correlation coefficients are statistically significant at the $95 \%$ confidence level and compare well with those observed between VV300 and NAO (Fig. 8b). The negative correlations over the eastern part of North Atlantic and the Mediterranean $\left(25^{\circ} \mathrm{N}-40^{\circ} \mathrm{N}, 30^{\circ} \mathrm{W}-\right.$ $20^{\circ} \mathrm{E}$ ) could suggest that when the NAO index is positive, $\mathrm{CCC}$ is lower than normal in the area, possibly due to enhanced sinking of air masses in the area caused by a stronger than usual high pressure system at Azores while less frequent west-east advection of moisture and more cold and dry air penetrations from north to southeast Europe is taking place. As we move to the north, the correlation coefficients over northern Europe and the eastern part of NAFC $\left(50^{\circ} \mathrm{N}-65^{\circ} \mathrm{N}\right.$, $20^{\circ} \mathrm{W}-10^{\circ} \mathrm{E}$ ) are less statistically significant and cover a smaller area when compared to those between VV300 and NAO. Possibly, this could be explained by the fact that during the wintertime there are limited satellite cloud observations by ISCCP over $57^{\circ}$, and in that case our correlation results over $57^{\circ}$ are likely to be underestimated. However, it should be considered that other factors i.e. existence of complicated weather conditions and high natural cloud variability during the wintertime in the area may also mask this issue.

Figure 9 shows the time series of the anomalies of CCC from 1984 to 2004 versus NAO index during the wintertime over (a) the eastern part of the North Atlantic and the Mediterranean $\left(25^{\circ} \mathrm{N}-40^{\circ} \mathrm{N}, 30^{\circ} \mathrm{W}-20^{\circ} \mathrm{E}\right)$ and (b) northern Europe and the eastern part of NAFC $\left(50^{\circ} \mathrm{N}-65^{\circ} \mathrm{N}, 20^{\circ} \mathrm{W}-\right.$ $10^{\circ} \mathrm{E}$ ). From Fig. 9 it appears that $\mathrm{CCC}$ is anti-correlated with NAO index over the eastern part of the North Atlantic and the Mediterranean ( $R=-0.5$, significant at the $95 \%$ confidence level) and positively correlated over northern Europe and the eastern part of NAFC $(\mathrm{R}=+0.3$, significant at the $90 \%$ confidence level), confirming the correlation results of Fig. 8a.

As in the case of ENSO, we also calculated the percent of the interannual variance of CCC explained by NAO over the two regions by reconstructing the time series of CCC from NAO index based on Eq. (3). The reconstructed time series of $\mathrm{CCC}$ at the two locations is shown in Fig. 9 by the lines with grey colour. The annual mean CCC, the amplitude of the annual cycle, the interannual variance explained by NAO, and the long-term trends of CCC over the studied regions are summarised in Table $2 \mathrm{~b}$. As can be seen from Table $2 b$, over the eastern part of the North Atlantic and the Mediterranean $\left(25^{\circ} \mathrm{N}-40^{\circ} \mathrm{N}, 30^{\circ} \mathrm{W}-20^{\circ} \mathrm{E}\right)$ the amplitude of 


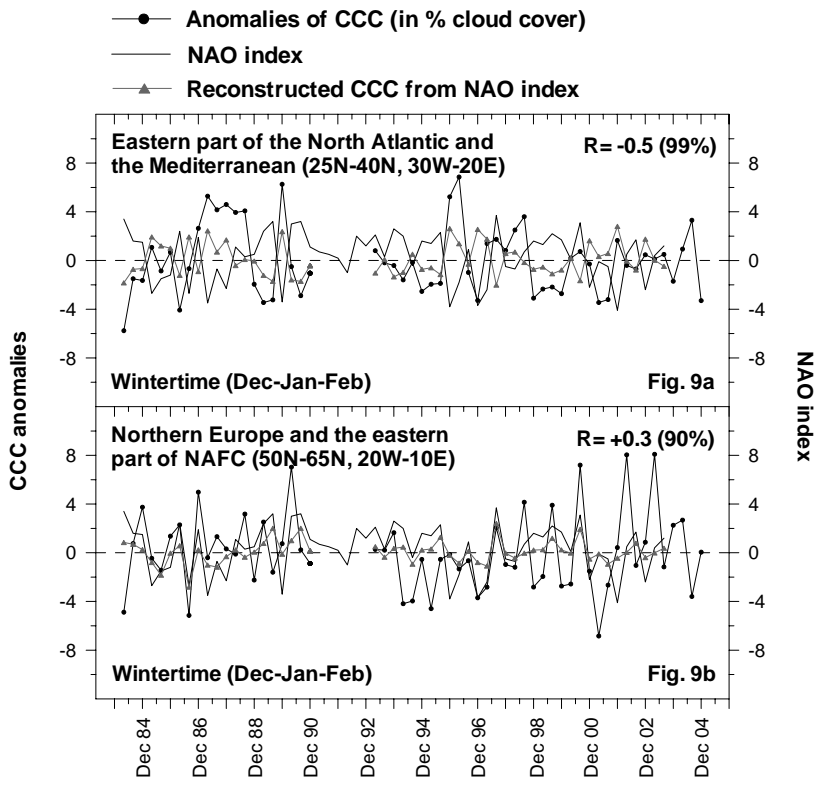

Fig. 9. (a) Time series of CCC anomalies and NAO index from 1984 to 2004 during the wintertime (December, January and February) over the eastern part of the North Atlantic and the Mediterranean $\left(25^{\circ} \mathrm{N}-40^{\circ} \mathrm{N}, 30^{\circ} \mathrm{W}-20^{\circ} \mathrm{E}\right)$. (b) Same as (a) but for northern Europe and the eastern part of NAFC $\left(50^{\circ} \mathrm{N}-65^{\circ} \mathrm{N}, 20^{\circ} \mathrm{W}-10^{\circ} \mathrm{E}\right) . R$ is the correlation coefficient between the two lines. Values in brackets refer to statistical significance of $R$. With grey colour is shown the reconstructed time series of CCC from NAO index at the two locations, indicating the interannual variance of $\mathrm{CCC}$ explained by NAO (in \% cloud cover).

the annual cycle of $\mathrm{CCC}$ is $3.6 \%$ and the interannual variance of CCC explained by NAO is up to $2.4 \%$. Accordingly, over northern Europe and the eastern part of NAFC $\left(50^{\circ} \mathrm{N}-65^{\circ} \mathrm{N}\right.$, $20^{\circ} \mathrm{W}-10^{\circ} \mathrm{E}$ ) the interannual variance of $\mathrm{CCC}$ explained by $\mathrm{NAO}$ is up to $2.6 \%$ and it is also smaller than the amplitude of the annual cycle (3.1\% cloud cover). Therefore, in northern mid-latitudes the percent of the interannual variance of CCC explained by NAO does not exceed the amplitude of the annual cycle.

Furthermore, to evaluate the significance of the anthropogenic (aviation) effect with respect to the natural variability we have compared our results with manmade longterm trends over Europe and the NAFC as evidenced from earlier studies (Zerefos et al., 2003; Stordal et al., 2005; Stubenrauch and Schumann, 2005). According to Sausen et al. (1998), at altitude levels around $300 \mathrm{hPa}$ regions that are susceptible to the formation of contrails are located more in the extra-tropics than over the tropics. Over Europe and the NAFC, flight frequencies and flight consumption are high (shown, for example, in Fig. 1 of Zerefos et al., 2003) and situations favourable for contrail formation have been estimated to occur about $7 \%$ over Europe and $5 \%$ over the NAFC (Stubenrauch and Schumann, 2005). Therefore, over Europe and the NAFC it is possible that cirrus amounts may also in- clude persistent contrails and therefore the cirrus trends can be explained not only by natural long-term variability, but also by variability in manmade cirrus contrails. As can be seen from Table $2 b$, there is a positive trend in CCC over northern Europe and the eastern part of NAFC, which in the long-term amounts to about $+1.6 \%$ per decade. This trend has been calculated after removing from the time series of CCC the fraction of the natural variability that is explained by NAO (shown in Fig. $9 b$ by the grey line). This trend is statistically significant at the $95 \%$ confidence level and compares well with the observed positive manmade trends in cirrus clouds over congested air traffic regions in Europe and the North Atlantic as have been evidenced from earlier studies (Zerefos et al., 2003; Stordal et al., 2005; Stubenrauch and Schumann, 2005). On the other hand, over the other region which is influenced by NAO $\left(25^{\circ} \mathrm{N}-40^{\circ} \mathrm{N}, 30^{\circ} \mathrm{W}-\right.$ $20^{\circ} \mathrm{E}$ ), there is a negative trend in CCC of about $-0.5 \%$ per decade, which follows the large-scale negative trends in CCC observed by ISCCP over most of the northern mid-latitudes. It should be noted that the respective trends in VV300 over the two studied areas are of the same sign (the order of $+1.5 \mathrm{mPa} / \mathrm{s}$ per decade), which suggests that the differences in trends in CCC over the two regions cannot be attributed to differences in trends in vertical winds.

Possible effects of the stratospheric Quasi Biennal Oscillation $(\mathrm{QBO})$ on cirrus clouds were also examined but there were no significant correlations between the two parameters (correlation coefficients less than 0.2 ). The correlation coefficients were small even for different month lags $(-24,-18$, $-12,-6,0,6,12,18,24)$ as well as for the pair VV300QBO, providing indications that the stratospheric QBO does not affect the distribution and variability of upper tropospheric cirrus clouds.

\section{Summary and conclusions}

This study analysed globally cirrus cloud data from the ISCCP D2 1984-2004 dataset and calculated the percent of the interannual variance of CCC explained by ENSO, NAO and QBO. The major findings and conclusions can be summarised as follows:

The variability of cirrus clouds is different over different geographical regions and originates from different causes. CCC was found to be strongly correlated with large-scale vertical velocities and relative humidity in the tropics (correlations with vertical velocities up to -0.7 at some locations and with relative humidity up to +0.7 ), suggesting that variations in large-scale vertical winds and relative humidity fields explain the origin of up to half or more of the local variability in CCC over these regions. These correlations reflect mostly the seasonal cycle, indicated by the close seasonal match of the examined parameters. The highest amounts of cirrus clouds in all seasons were found in the tropics in agreement with earlier findings. In the tropics, the annual mean cirrus 
coverage is about $20 \%$ and the amplitude of the annual cycle is $2.7 \%$. The amplitude of annual cycle is almost symmetric about the equator peaking at $15^{\circ} \mathrm{N}$ and $15^{\circ} \mathrm{S}$ to about $7-8 \%$ of total cloud cover. Its latitudinal distribution reflects the extent and the seasonal shifts of the Hadley circulation cell. Over the middle latitudes the amplitude of the annual cycle is smaller than over the subtropics reaching a maximum of 5\% in the Northern Hemisphere. Globally $\left(60^{\circ} \mathrm{N}-60^{\circ} \mathrm{S}\right)$, cirrus clouds cover about $14 \%$ of the Earth's upper troposphere (ISCCP 1984-2004 annual average) and the amplitude of the annual cycle is about $1.2 \%$.

Although the annual cycle is dominant in all latitudes and longitudes, peaking over the tropics and subtropics, its amplitude is exceeded during strong El Nino/La Nina events. Over the eastern tropical Pacific Ocean $\left(10^{\circ} \mathrm{N}-10^{\circ} \mathrm{S}\right.$, $80^{\circ} \mathrm{W}-180^{\circ} \mathrm{W}$ ) the annual mean $\mathrm{CCC}$ is $12.5 \%$ and the amplitude of the annual cycle is 3\%. However during ENSO, the interannual variance of CCC explained by ENSO is $6.8 \%$ and it is about 2.3 times larger than the amplitude of the annual cycle at these regions. The effects of NAO and QBO on natural cirrus cloudiness in the tropics were found to be small. Natural long-term trends in CCC in the tropics and subtropics are generally small (between $-0.3 \%$ and $-0.7 \%$ per decade) excluding the south extra tropics where no trends have been observed. Possible manmade trends in the tropics are small.

In the northern mid-latitudes, on the other hand, the effect of NAO is more significant and can be very important regionally. More specifically, over the region bounded by latitudes $25^{\circ} \mathrm{N}-40^{\circ} \mathrm{N}$ and by longitudes $30^{\circ} \mathrm{W}-20^{\circ} \mathrm{E}$ (eastern part of the North Atlantic and the Mediterranean) cirrus clouds are negatively correlated with NAO index during the wintertime by about -0.5 . Over the region between $50^{\circ} \mathrm{N}-$ $65^{\circ} \mathrm{N}$ and $20^{\circ} \mathrm{W}-10^{\circ} \mathrm{E}$ (northern Europe and the eastern part of NAFC) the correlation is positive $(+0.3)$. These correlations are statistically significant at the $90 \%$ confidence level and compare well with those observed between the vertical velocities at $300 \mathrm{hPa}$ and NAO. Over northern Europe and the eastern part of NAFC the percent of the interannual variance of CCC which is explained by NAO is $\sim 2.6 \%$ and it is smaller than the amplitude of the annual cycle $(3.1 \%$ cloud cover). After removing the fraction of the interannual variance that is explained by NAO, we find a significant increasing trend in $\mathrm{CCC}$ of about $+1.6 \%$ per decade. This trend may be related to manmade cirrus contrails. On the other hand, over the other region which is influenced by NAO $\left(25^{\circ} \mathrm{N}-\right.$ $40^{\circ} \mathrm{N}, 30^{\circ} \mathrm{W}-20^{\circ} \mathrm{E}$ ), there is a negative trend in CCC which follows the general negative trends observed by ISCCP over most of the northern mid-latitudes. QBO and ENSO were not found to be significantly correlated with variations in cirrus clouds over the northern mid-latitudes.

The results of this work can be used to evaluate cirrus cloud cover and variability in climate model simulations. It is important for the climate models to get the cirrus covers right and this work can form the basis for an evaluation of both the mean cirrus cover and scales of variability but also can give modellers a chance to examine whether the models simulate the dependence of cirrus cover on basic dynamic and thermodynamic parameters. The global relationships between cirrus cloud cover and seasonal variability, ENSO and NAO derived in this paper can be tested in climate model simulations in order to quantify cirrus cloud dependencies in the model atmosphere. This would allow modellers to attribute model cirrus cloud deficiencies to either incorrect representation of atmospheric dynamics processes or to problems in the parameterization of cirrus cloud formation.

Acknowledgements. This study was conducted within the FP6 Integrated Project "Quantifying the Climate Impact of Global and European Transport Systems" (QUANTIFY, Contract No 003893GOCE) and contributes to the ECATS Network of Excellence, both funded by the European Commission. The study also contributes to the national project PENED (O3ED57) funded by the General Secretariat of Research and Technology. We would like to thank A. Sheffield from NASA/GISS for her assistance in the analysis of the equal-angle map grid of ISCCP D2 dataset. We also thank the reviewers who have helped improving the study.

Edited by: A. Nenes

\section{References}

Bourassa, A. E., Degenstein, D. A., and Llewellyn, E. J.: Climatology of the subvisual cirrus clouds as seen by OSIRIS on Odin, Adv. Space Res., 36, 807-812, 2005.

Cess, R. D., Zhang, M., Wang, P.-H., and Wielicki, B. A.: Cloud structure anomalies over the tropical Pacific during the 1997/98 El Nino, Geophys. Res. Lett., 28, 4547-4550, 2001.

Chen, B. and Liu, X.: Seasonal migration of cirrus clouds over the Asian Monsoon regions and the Tibetan Plateau measured from MODIS/Terra, Geophys. Res. Lett., 32, L01804, doi:10.1029/2004GL020868, 2005.

Dessler, A. E. and Yang, P.: The Distribution of Tropical Thin Cirrus Clouds Inferred from Terra MODIS Data, J. Climate, 16, 1241-1247, 2003.

Gierens, K., Schumann, U., Helten, M., Smit, H. G. J., and Marenco, A.: A distribution law for relative humidity in the upper troposphere and lower troposphere derived from three years of MOZAIC measurements, Ann. Geophys., 17, 1218-1226, 1999 , http://www.ann-geophys.net/17/1218/1999/.

Gierens, K., Schumann, U., Helten, M., Smit, H., and Wang, P. H.: Ice-saturated regions and subvisible cirrus in the northern midlatitude upper troposphere, J. Geophys. Res, 105, $22743-$ $22754,2000$.

Jensen, E. J., Toon, O. B., Selkirk, H. B., Spinhirne, J. D., and Schoeberl, M. R.: On the formation and persistence of subvisible cirrus clouds near the tropical tropopause, J. Geophys. Res., 101(D16), 21 361-21375, 1996.

Liao, X, Rossow, W. B., and Rind, D.: Comparison between SAGE II and ISCCP high-level clouds, 1. Global and zonal mean cloud amounts, J. Geophys. Res., 100(D1), 1121-1135, 1995. 
Liou, K. N.: Influence of cirrus clouds on weather and climate processes: a global perspective, Mon. Wea. Rev., 114, 1167-1199, 1986.

Lohmann, U. and Feichter, J.: Global indirect aerosol effects: a review, Atmos. Chem. Phys., 5, 715-737, 2005, http://www.atmos-chem-phys.net/5/715/2005/.

Luo, Z., Rossow, W. B., Inoue, T., and Stubenrauch, C. J.: Did the Eruption of the Mt. Pinatubo Volcano Affect Cirrus Properties?, J. Climate, 17, 2806-2820, 2002.

Lynch, D. K.: Cirrus clouds: Their role in climate and global change, Acta Astronautica, 38(11), 859-863, 1996.

Massie, S., Lowe, P., Tie, X., Hervig, M., Thomas, G., and Russell III, J.: Effect of the 1997 El Nino on the distribution of upper tropospheric cirrus, J. Geophys. Res., 105(D18), 22 725-22 741, 2000.

Mergenthaler, J. L., Roche, A. E., Kumer, J. B., and Ely, G. A.: Cryogenic Limb Array Etalon Spectrometer observations of tropical cirrus, J. Geophys. Res., 104, 22 183-22 194, 1999.

Minnis, P., Ayers, J. K., Palikonda, R., and Phan, D.: Contrails, Cirrus Trends, and Climate, J. Climate, 17, 1671-1685, 2004.

Rossow, W. B. and Schiffer, R. A.: ISCCP Cloud data products, Bull. Amer. Meteorol. Soc., 72, 2-20, 1991.

Rossow, W. B., Walker, A. W., Beuschel, D. E., and Roiter, M. D.: International Satellite Cloud Climatology Project (ISCCP) Documentation of New Cloud Datasets, WMO/TD 737, World Climate Research Programme, Geneva, Switzerland, 1996.

Rossow, W. B. and Schiffer, R. A.: Advances in understanding clouds from ISCCP, Bull. Amer. Meteorol. Soc., 80, 2261-2287, 1999.

Sandor, B. J., Jensen, E. J., Stone, E. M., Read, W. G., Waters, J. W., and Mergenthaler, J. L.: Upper tropospheric humidity and thin cirrus, Geophys. Res. Lett., 27(17), 2645-2648, 2000.

Sassen, K. and Campbell, J. R.: A Midlatitude Cirrus Cloud Climatology from the Facility for Atmospheric Remote Sensing. Part I: Macrophysical and Synoptic Properties, J. Atmos. Sci., 58, 481496, 2001.

Sausen, R., Gierens, K., Ponater, M., and Schumann, U.: A diagnostic study of the global distribution of contrails, part I: present day climate, Theor. Appl. Climatol., 61, 127-141, 1998.

Sausen, R., Isaksen, I., Grewe, V., Hauglustaine, D., Lee, D. S., Myhre, G., Köhler, M. O., Pitari, G., Schumann, U., Stordal, F., and Zerefos, C.: Aviation radiative forcing in 2000: An update on IPCC (1999), Meteorol. Z., 14(4), 555-561, 2005.

Schumann, U.: Formation, properties and climate effects of contrails, C. R. Physique, 6, 549-565, 2005.

Spichtinger, P., Gierens, K., and Read, W.: The global distribution of ice-supersaturated regions as seen by the microwave limb sounder, Quart. J. Roy. Meteorol. Soc., 129, 3391-3410, 2003.
Spichtinger, P., Gierens, K., and Dörnbrack, A.: Formation of ice supersaturation by mesoscale gravity waves, Atmos. Chem. Phys., 5, 1243-1255, 2005, http://www.atmos-chem-phys.net/5/1243/2005/.

Stordal, F., Myhre, G., Stordal, E. J. G., Rossow, W. B., Lee, D. S., Arlander, D. W., and Svendby, T.: Is there a trend in cirrus clouds cover due to aircraft traffic?, Atmos. Chem. Phys., 5, 2155-2162, 2005 , http://www.atmos-chem-phys.net/5/2155/2005/.

Stubenrauch, C. J. and Schumann, U.: Impact of air traffic on cirrus coverage, Geophys. Res. Lett., 32, L14813, doi:10.1029/2005GL022707, 2005.

Tselioudis, G. and Jakob, C.: Evaluation of midlatitude cloud properties in a weather and a climate model: dependence on dynamic regime and spatial resolution, J. Geophys. Res., 107(D24), AAC-14, 2002.

Wang, P.-H., Minnis, P., McCormick, M. P., Kent, G. S., and Skeens, K. M.: A 6-year climatology of cloud occurrence frequency from Stratospheric Aerosol and Gas Experiment II observations (1985-1990), J. Geophys. Res., 101, 29407-29429, 1996.

Wang, P. H., Minnis, P., Wielicki, B. A., Wong, T., and Vann, L. B.: Satellite observations of long-term changes in tropical cloud and outgoing longwave radiation from 1985 to 1998, Geophys. Res. Lett., 29, 1397, doi:10.1029/2001GL014264, 2002.

Wang, P.-H., Minnis, P., Wielicki, B. A., Wong, T., Cess, R. D., Zhang, M., Vann, L. B., and Kent, G. S.: Characteristics of the 1997/1998 El Nino cloud distributions from SAGE II observations, J. Geophys. Res., 108(D1), 4009, doi:10.1029/2002JD002501, 2003.

Woodbury G. E. and McCormick, M. P.: Zonal and Geographical Distributions of Cirrus Clouds Determined From SAGE Data, J. Geophys. Res., 91(D2), 2775-2785, 1986.

Wylie, D. P. and Menzel, W. P.: Eight Years of High Cloud Statistics Using HIRS, J. Climate, 12, 170-184, 1999.

Zerefos, C. S., Tourpali, K., and Bais, A. F.: Further studies on possible volcanic signal to the ozone layer, J. Geophys. Res., 99, 25 741-25 746, 1994.

Zerefos, C. S., Eleftheratos, K., Balis, D. S., Zanis, P., Tselioudis, G., and Meleti, C.: Evidence of impact of aviation on cirrus cloud formation, Atmos. Chem. Phys., 3, 1633-1644, 2003, http://www.atmos-chem-phys.net/3/1633/2003/.

Zerefos, C. S., Eleftheratos, K., Zanis, P., Balis, D. S., and Tselioudis, G.: Search for manmade cirrus-contrails over Southeast Asia, Special Issue of East Asia Climate and Environment (EACE) in TAO, in press, 2007. 